\title{
Effect of Dietary Monensin Supplementation on Nitrogen utilization and Plasma metabolites in Lactating Murrah Buffaloes
}

\author{
Shiva Gupta ${ }^{1 *}$, Madhu Mohini ${ }^{2}$, S.S. Thakur ${ }^{2}$ and Goutam Mondal ${ }^{2}$ \\ ${ }^{1}$ Department of Animal Husbandry, Madhya Pradesh, India \\ ${ }^{2}$ DCN Division, NDRI, Karnal-132001 (Haryana), India \\ *Corresponding author
}

\section{A B S T R A C T}

The present study was conducted to evaluate the efficacy of monensin supplementation in nitrogen balance and blood metabolites in lactating murrah buffaloes receiving concentrate and sugar graze fodder. Twelve lactating Murrah buffaloes $(567.50 \pm 44.3 \mathrm{~kg}$ of live weight; initial days in milk $=52.83 \pm 10.24$; milk yield $=6-8 \mathrm{~kg} / \mathrm{d}$ ) were randomly allocated to two groups and were fed sugar graze and concentrate mixture as a total mixed ration feed at 70:30 ratio without supplementation (control) or supplemented with monensin $24 \mathrm{mg} / \mathrm{kg}$ of dry matter intake (monensin) for 60 days. Nitrogen utilization and plasma metabolites were measured after $50^{\text {th }}$ day of monensin supplementation. Intake of nitrogen and outgo of urinary, faecal, milk and total nitrogen $(\mathrm{g} / \mathrm{d})$ were not $(\mathrm{P}>0.05)$ affected by monensin supplementation. However, nitrogen retention $(\mathrm{g} / \mathrm{d})$ and blood plasma glucose $(\mathrm{mg} / \mathrm{dl})$ concentration increased $(\mathrm{P}<0.05)$ in treatment group as compared to control. The concentration of blood non-estrified fatty acid, blood urea nitrogen, total protein and albumin were not affected $(\mathrm{P}>0.05)$ by monensin supplementation. The results suggest that feeding $24 \mathrm{mg} / \mathrm{kg}$ dry matter intake of monensin on high forage diets has potential to improve nitrogen utilization and blood glucose concentration in lactating buffaloes which will help in improving profitability of dairy sector while reducing the environmental impact of milk production.

\section{Introduction}

In India, livestock rearing is a basic component of the agriculture production system, and plays an important role in the Indian economy $(4.11 \%$ of the total GDP in 2012-2013 BAHS, (2014) and socioeconomic development of millions of rural households (MOA, 2008). Indian livestock have the highest share of the world livestock population (FAO, 2006). India is the world's largest milk producer; accounting for more than $18.5 \%$ of the world's total milk production (GOI, 2016) and buffaloes contribute the highest $(49.2 \%)$ share to milk production in India (Basic Animal Husbandry Statistics, 2017). In agriculture sector, waste from animal production system contribute as much as $30-50 \%$ to the global $\mathrm{N}_{2} \mathrm{O}$ emissions but relatively little attention has been given on developing mitigation options (Oenema et al., 2005). Buffalo is a triple purpose animal, 
being suitable for milk, meat and draught. The crude protein concentration of ruminant diet essentially nitrogen concentrations of consumed feedstuffs often limit ruminant production (Craine et al., 2010). Dietary protein is used inefficiently by dairy animals compared to non-ruminants, with approximately $72 \%$ of nitrogen intake excreted in manure (Mills et al., 2009). This low efficiency of dietary nitrogen utilization is attributable primarily to the effects of the rumen on dietary nitrogen utilization (Calsamiglia et al., 2009). Nitrogen excretion in urine and faeces is a significant environmental concern due to nitrate $\left(\mathrm{NO}_{3}\right)$ leaching contributing to aquatic eutrophication, as well as effects on air quality and greenhouse gas emissions through gaseous losses as ammonia $\left(\mathrm{NH}_{3}\right)$ and nitrous oxide $\left(\mathrm{N}_{2} \mathrm{O}\right)$. Dong et al., (2014) stated that intake of nitrogen identified as the main driver of ruminant nitrogen excretion. Excess nitrogen release by ruminants can directly cause leaching and soil nutrient imbalance (Marini and Van Amburgh, 2005). Excess nitrogen can be converted to nitrous oxide which is a greenhouse gas with potential that is around 300 times that of carbon dioxide (Eckard et al., 2010). Nitrogen excreted by ruminants is not utilized for growth and production and may negatively impact the environment. The efficiency of nitrogen retention and utilization by buffaloes play an important role in environmental relevance (Tamminga, 1996). In ruminant production systems it is beneficial to reduce the environmental release of nitrogen in urine and faeces by improve the efficiency of nitrogen utilization. Ionophores regulate the movement of monovalent cations across cell membranes of Gram-positive bacteria and protozoa, disrupting their normal function (Duffield and Bagg 2000). Monensin is a monovalent carboxylic polyether ionophore produced by Streptomyces cinnamonensis and most commonly used ionophore to improve the efficiency of production (meat and milk) in ruminants (Rodehutscord, 2013). Monensin supplementation improves nitrogen metabolism and reduced proteolysis of intake of feed protein because of its protein sparing characteristics (Poos et al., 1979). The inclusion of monensin in ruminants diet may benefit air quality by reducing $\mathrm{CH}_{4}$ and nitrogen emissions and water quality by reducing nitrogen in manure, which can potentially leave the farm through leaching into ground water and through runoff into surface (Tedeschi et al., 2003). Therefore, various rumen modifiers including monensin have been used in ruminats to increase feed utilization, and production performance while reducing/maintaining environmental impact of milk production. Pambu- Gollah et al., (2000) stated that blood metabolites give rapid indication of an animal nutritional level at the particular point of time. Cinar and Sulu, (1995) reported that blood glucose level increased by monensin supplementation due to higher propionate production which is glucogenic in nature or could be due to shifting of digestion of starch and other soluble sugars from rumen to lower tract, from where it is absorbed as glucose (Haimoud et al., 1995). Therefore, the objectives of the present study were to evaluate the effects of monensin supplementation on nitrogen utilization and plasma metabolites of lactating buffaloes.

\section{Materials and Methods}

The experimental protocol was approved by Institutional Animal Ethics Committee (IAEC/09/16 dated 05.11.2016) of the National Dairy Research Institute, Karnal, India. The study was conducted in the experimental animal shed at Livestock Research Center of National Dairy Research Institute, Karnal, India, located at an altitude of 250 meter above the mean sea level on $29.43^{\circ} \mathrm{N}$ latitude and $72.2^{\circ} \mathrm{E}$ longitude. The 
maximum ambient temperature goes up to $45^{\circ} \mathrm{C}$ during summer, minimum about $5^{\circ} \mathrm{C}$ during winter, relative humidity varies from 18 to 97 percent with an annual rain fall is approximately $760-960 \mathrm{~mm}$ most of which is received during the months of July to August. (Central Soil Salinity Research Institute, Karnal, Haryana). The present experiment was conducted during mid-December to midFebruary. Twelve lactating Murrah buffaloes having average body weight of (567.50 \pm 44.3 $\mathrm{kg}$ of live weight; initial days-in milk $=52.83$ \pm 10.24 ; milk yield $=6-8 \mathrm{~kg} / \mathrm{d}$ ) were selected from the Institute Livestock Research Centre and identified by numbered ear tags, tethered with nylon rope individually in a wellventilated stall (floor space $=4 \mathrm{~m}^{2}$ per animal) provided with uniform management practices and having facilities for individual feeding. Animals were dewormed using Fenbendazole (Panacur®, Intervet, India) at $10 \mathrm{mg} / \mathrm{kg} \mathrm{BW}$ and treated against ectoparasites using Deltamethrin (Butox®) spray $10 \mathrm{~d}$ before the commencement of experimental feeding. After an adaptation period of 10 days, animals were randomly divided into two groups of six animals in each on the basis of body weight. Both groups were fed ration comprising of green sugar graze fodder chopped at $2-3 \mathrm{~cm}$ length, concentrate mixture (in $\mathrm{g} / \mathrm{kg}$ as mixed: maize 330, groundnut cake 180, mustard oil cake 100 , cotton seed cake 50 , wheat bran 200 , de-oiled rice bran 60 , bajra 50 , mineral mixture 20 and common salt 10) and concentrate mixture (70:30) without and with monensin supplementation $(24 \mathrm{mg} / \mathrm{kg}$ of dry matter intake) in control and treatment group, respectively for sixty days. Monensin was top dressed on concentrate mixture in the form of Rumensin (Elanco, Division of Eli Lilly and company (NZ Limited), which contains monensin in a concentration of $20 \%$ Mill mix (Equivalent to $200 \mathrm{~g}$ of monensin activity as monensin sodium per $\mathrm{kg}$ ). All animals were provided clean and fresh drinking water twice daily in morning at $10.00 \mathrm{~h}$ and evening at
17:30 h. The metabolism study with 3 days adaptation period followed by 7 days collection period was conducted after 50 days of experimental feeding trial, during which daily intake of feeds and output of faeces and urine were recorded. For nitrogen (N) determination (Kjeldahl method) faeces samples (1/500 of daily voidance) were preserved in $30 \%$ sulphuric acid to make pooled samples of $7 \mathrm{~d}$ for individual animals. Total daily voided of urine for $24 \mathrm{~h}$ was collected in plastic containers containing 25 $\mathrm{ml}$ of $25 \%$ sulphuric acid solution. An aliquot $(0.5 \%$ of total urine output) was collected from the acidified urine for $\mathrm{N}$ estimation (Kjeldahl method). Blood samples $(10 \mathrm{ml})$ were collected at zero day and last day of animal trial $\left(60^{\text {th }}\right.$ day $)$ in sterile heparinised vacutainer tubes from jugular vein puncture, posing minimum disturbance to the animal. Immediately after collection, samples were kept in ice box and transported to the laboratory for further processing. The plasma was separated by centrifugation at $3000 \mathrm{rpm}$ for 30 minutes and stored at $20^{\circ} \mathrm{C}$ in different aliquots analysed for glucose, blood urea nitrogen, total protein and albumin using diagnostic reagent kit provided by Recombigen Laboratories PVT. LTD (New delhi). Plasma NEFA concentration was estimated by copper soap solvent extraction method modified by Shipe et al., (1980).

\section{Results and Discussion}

Chemical composition of ingredients of basal diet are presented in Table 1. The chemical composition of all the ingredients were within normal range reported previously (Das et al., 2014, Prusty, 2015, and Sharma, 2017).

Effect of dietary monensin supplementation on nitrogen utilization in lactating buffaloes is presented in Table 2. Average $\mathrm{N}$ intake $(\mathrm{g} / \mathrm{d})$ was $310.04 \pm 9.35$ and $298.10 \pm 4.84$ in control and treatment group, respectively and did not 
differ $(\mathrm{P}>0.05)$ between the two groups. There was no significant difference in $\mathrm{N}$ excretion in faeces, urine and milk, total $\mathrm{N}$ out go, $\mathrm{N}$ absorption and $\mathrm{N}$ retention between the two groups. Thus efficiency of protein utilization of the rations was similar with and without monensin supplementation in lactating buffaloes. Overall $\mathrm{N}$ balance $(\mathrm{g} / \mathrm{d})$ was higher $(\mathrm{P}<0.05)$ in monensin supplemented group $(9.05 \pm 0.23)$ in comparison to control (7.62 \pm 0.57$)$. This improvement in $\mathrm{N}$ absorption might be due to improvement in lower tract digestibility (Haimoud et al.,
1995). According to Duffield et al., (2008) monensin responsible for better nitrogen utilization as available amino acids in the intestine, resulting from changes in rumen fermentation. Monensin has the ability to select and decreases the population of the bacteria that degrade amino acids in the rumen environment and causes deamination. This increased flow of protein to the small intestine will up-regulate the amino acid uptake capacity of the small intestine (Gandra et al., 2012).

Table.1 Chemical composition and energy contents of offered feedstuffs

\begin{tabular}{|c|c|c|}
\hline Parameter (\%DM) & $\begin{array}{c}\text { Concentrate } \\
\text { Mixture }\end{array}$ & $\begin{array}{c}\text { Sugar graze } \\
\text { Green fodder }\end{array}$ \\
\hline DM & 90.39 & 25.21 \\
\hline OM & 94.54 & 90.41 \\
\hline CP & 21.78 & 10.75 \\
\hline EE & 3.9 & 1.73 \\
\hline NA & 5.45 & 9.59 \\
\hline NDF & 44.77 & 17.91 \\
\hline ADF & 24.1 & 60.02 \\
\hline Hemicellulose & 11.49 & 36.16 \\
\hline Cellulose & 12.6 & 23.86 \\
\hline ADL & 6.87 & 30.98 \\
\hline TDN & 3.96 & 5.18 \\
\hline DE (MJ/kg DM) & 76.33 & 56.30 \\
\hline ME (MJ/kg DM) & 14.08 & 10.39 \\
\hline
\end{tabular}

Table.2 Effect of dietary monensin supplementation on nitrogen utilization in lactating Murrah buffaloes

\begin{tabular}{|c|c|c|c|}
\hline Parameter & Control & Treatment & P value \\
\hline N Intake (g/d) & $310.04 \pm 9.35$ & $298.10 \pm 4.84$ & 0.24 \\
\hline Faecal N outgo (g/d) & $122.26 \pm 6.91$ & $115.02 \pm 2.15$ & 0.23 \\
\hline Urine N outgo (g/d) & $119.63 \pm 4.22$ & $112.00 \pm 3.81$ & 0.26 \\
\hline Milk N (g/d) & $60.52 \pm 1.41$ & $62.04 \pm 2.11$ & 0.65 \\
\hline Total N excretion (g/d) & $302.42 \pm 9.82$ & $289.06 \pm 4.94$ & 0.21 \\
\hline N balance (g/d) & $7.62^{\mathrm{b}} \pm 0.57$ & $9.05^{\mathrm{a}} \pm 0.23$ & 0.03 \\
\hline Absorption $(\%$ of intake) & $60.55 \pm 1.06$ & $61.23 \pm 0.62$ & 0.57 \\
\hline N retained $(\%$ of intake) & $2.30 \pm 0.28$ & $2.60 \pm 0.15$ & 0.33 \\
\hline
\end{tabular}

Means bearing different superscripts ${ }^{\mathrm{a}, \mathrm{b}}$ in the same row differ significantly $(\mathrm{P}<0.05)$ 
Table.3 Effect of Monensin supplementation on plasma metabolites in lactating buffaloes

\begin{tabular}{|c|c|c|c|c|}
\hline Parameter & Days & Control & Treatment & P value \\
\hline $\begin{array}{c}\text { Blood glucose } \\
(\mathbf{m g} / \mathbf{d l})\end{array}$ & Zero day & $49.56 \pm 0.41$ & $49.51 \pm 0.65$ & 0.96 \\
\cline { 2 - 5 } & $60^{\text {th }}$ day & $51.93 \pm 0.84$ & $55.39 \pm 0.71$ & 0.02 \\
\hline \multirow{2}{*}{ BUN $(\mathbf{m g} / \mathbf{d l})$} & Zero day & $23.07 \pm 0.20$ & $23.03 \pm 0.10$ & 0.79 \\
\cline { 2 - 5 } & $6^{\text {th }}$ day & $22.90 \pm 0.91$ & $21.29 \pm 0.84$ & 0.87 \\
\hline \multirow{2}{*}{ NEFA $(\boldsymbol{\mu m o l} / \mathbf{l})$} & Zero day & $141.50 \pm 3.12$ & $142.67 \pm 2.39$ & 0.77 \\
\cline { 2 - 5 } & $6^{\text {th }}$ day & $138.16 \pm 0.90$ & $137.67 \pm 0.84$ & 0.70 \\
\hline \multirow{2}{*}{$\begin{array}{c}\text { Total Protein } \\
(\mathbf{m g} / \mathbf{d l})\end{array}$} & Zero day $^{\text {th }}$ & $6.87 \pm 0.13$ & $6.85 \pm 0.14$ & 0.93 \\
\hline $\begin{array}{c}\text { Albumin } \\
(\mathbf{m g} / \mathbf{d l})\end{array}$ & Zero day $^{\text {th }}$ & $7.11 \pm 0.13$ & $7.15 \pm 0.15$ & 0.86 \\
\hline
\end{tabular}

Means bearing different superscripts ${ }^{\mathrm{a}, \mathrm{b}}$ in same row differ significantly $(\mathrm{P}<0.05)$

Based on these findings, it appeared that monensin altered the nitrogen excretion pattern and may increase the proportion of amino acids absorbed positively by increasing the quality and quantity of nitrogen absorbed.

The concentration of plasma metabolites for both the groups of lactating buffalo at zero day and at the end of experimental trial $\left(60^{\text {th }}\right.$ day) are presented in Table 3.

Ndlovu et al., (2007) reported that plasma concentrations of metabolites such as glucose, BUN, NEFA, Total protein, albumin, globulin and minerals reflect nutritional status of dairy cows. Blood glucose $(\mathrm{mg} / \mathrm{dl})$ concentration was similar at the day of start of experiment for control (49.56 \pm 0.41$)$ and treatment group $(49.51 \pm 0.65)$. However, there was increased $(\mathrm{P}<0.05)$ concentration of blood plasma glucose $(\mathrm{mg} / \mathrm{dl})$ in monensin supplemented group (55.39 \pm 0.71$)$ as compared to control ((51.93 \pm 0.84$)$ till the end of the experiment. These values are within normal physiological range and comparable with findings of previous study (Hagawane et al., 2009; Kalasariya et al., 2017 and Yogi, 2017). In consonance with our finding, Helal and Lasheen (2008), also reported significant increase in blood glucose concentration with monensin $(400 \mathrm{mg} / \mathrm{d})$ supplemented feed in lactating buffaloes. Propionate are the precursor for gluconeogenesis and its supply is increased by the action of ionophores in the rumen (Bauman and Elliot, 1983), this might be the possible explanation for increase in blood glucose in the monensin supplemented group. Blood urea nitrogen $(\mathrm{mg} / \mathrm{dl})$ concentration was similar for both the group at the day of start of experiment. At the end of animal trial concentration of blood urea nitrogen (BUN) was not differed in control $(22.90 \pm 0.91 \mathrm{mg} / \mathrm{dl})$ and monensin supplemented $(21.29 \pm 0.84 \mathrm{mg} / \mathrm{dl})$ group. These values are within normal physiological range and comparable with findings of Yogi (2017). Similar to present findings Lamba et al., (2013) observed that concentration of BUN was unaffected by monensin $(300 \mathrm{mg} / \mathrm{d})$ supplementation to lactating cows and monensin $(24 \mathrm{mg} / \mathrm{kg} \mathrm{DM})$ supplementation did not altered blood profile in mid lactation Holstein cows reported by Vendraminia et al., (2016). Plasma NEFA ( $\mu \mathrm{mol} / \mathrm{l})$ concentration was similar in both the groups at the day of start of experiment. At the end of the animal trial plasma level of NEFA $(\mu \mathrm{mol} / \mathrm{l}) \mathrm{did}$ not differ $(\mathrm{P}>0.05)$ in control $(138.16 \pm 0.90)$ and monensin supplemented (137.67 \pm 0.84$)$ group. In agreement to present study findings 
Mullins et al., (2011) reported no significant effect on plasma NEFA concentration in transition dairy cow fed ration supplemented with monensin (400mg/cow/day). On other hand Duffield et al., (2008) reported that monensin decrease NEFA concentration by a meta-analysis including 24 studies. Different response for blood NEFA concentration could be attributed to variation in type and composition of offered feedstuffs and species of animal. This difference might be due to animal species and their physiological stages. Initial blood plasma concentration of total protein $(6.87 \pm 0.13 ; 6.85 \pm 0.14 \mathrm{mg} / \mathrm{dl})$ and albumin $\quad(3.01 \pm 0.23 ; \quad 3.02 \pm 0.12 \mathrm{mg} / \mathrm{dl})$ concentrations was also similar in both the groups and at the end of the experimental trial blood plasma concentration of total protein $(7.11 \pm 0.13 ; 7.15 \pm 0.15)$ and albumin $(3.11 \pm 0.13 ; 3.15 \pm 0.15 \mathrm{mg} / \mathrm{dl})$ concentration was also not affected $(\mathrm{P}>0.05)$ by monensin supplementation. These values are within normal physiological range and comparable with findings of Yogi, (2017). Similar to findings of present study Helal and Lasheen, (2008) who reported no significant effect on plasma total proteins and albumin concentration in monensin (400mg/day) supplemented lactating buffaloes.

It was concluded that supplementation of monensin $(24 \mathrm{mg} / \mathrm{kg}$ of dry matter intake) to lactating Murrah Buffaloes increased blood glucose concentration indicating more available energy and could improve nitrogen utilization which will reduce the contribution of lactating buffaloes to green house gases emissions and their impact on the environment.

\section{Acknowledgements}

The authors express sincere thanks to the Director, NDRI, Karnal, for providing necessary facilities for this work. Financial assistance for the research was provided by
Indian Council of Agricultural Research (ICAR), New Delhi, India.

\section{References}

BAHS, 2014. Basic Animal Husbandry \& Fisheries Statistics, Department of Animal Husbandry, Dairying \& Fisheries, Ministry of Agriculture, Government of India, New Delhi.

Basic Animal Husbandry and Fisheries Statistics. 2017. Government of India, Ministry of Agriculture and Farmers Welfare, Department of Animal Husbandry, New Delhi.

Bauman, D. E., and J. M. Elliot. 1983. Control of nutrient partitioning in lactating ruminants. Biochemistry of Lactation. T. B. Mepham, ed. Elsevier Science Publishers, Amsterdam, the Netherlands. P 437-468.

Calsamiglia, S., A. Ferret, C. K. Reynolds, N. Kristensen, N., and A. M. van Vuuren. 2010.

Cinar, A. and N. Sulu. 1995. The effects of monensin on growth and development in calves. Twik Veterinerlik Ve Hay Vaneilik Dergisi., 19(6): 381-389.

Craine, J. M., Elmore, A. J., Olson K. C. and Tolleson, D. 2010. Climate change and nutritional stress in cattle. Glob. Change Biol. 16: 2901-2911.

Das, L. K., Kundu, S. S., Kumar, D. and Datt, C. 2014. Assessment of Energy Content of Some Tropical Concentrate Feeds of Ruminants using Model of National Research Council - 2001. Indian J. Sci. Technol., 7(12): 204212.

Dong, R.L., Zhao, G.Y., Chai, L.L. and Beauchemin, K.A. 2014. Prediction of urinary and fecal nitrogen excretion by beef cattle. J. Anim. Sci., 92: 46694681.

Duffield TF, Bagg RN. 2000. Use of ionophores in lactating dairy cattle: a 
review. Can Vet J. 41: 388.

Duffield, T. F., Rabiee, A. R. and Lean, I. J. 2008. A meta-analysis of the impact of monensin in lactating dairy cattle. $J$. Dairy Sci., 91: 1334-1346.

Duffield, T. F., Rabiee, A. R. and Lean, I. J. 2008. A meta-analysis of the impact of monensin in lactating dairy cattle. $J$. Dairy Sci., 91: 1334-1346.

Eckard, R.J., Grainger, C., de Klein C.A.M. 2010. Options for the abatement of methane and nitrous oxide from ruminant production. A review. Livest. Sci., 130:47- 56.

FAO. 2006. Steinfeld, H., Gerber, P., Wassenaar, T., Caste,1 V., Rosales, M. And de Haan, C. (eds) Livestock's long shadow. Environmental issues and options. Food and Agriculture Organization of the United Nations, Rome, ISBN: 978-92-5-105571-7.

Gandra, J. R., Renno, F. P., Junior, F., Esler, J., Filho, M. and Villela, B. R. 2012. Nutrients balances and milk fatty acid profile of mid lactation dairy cows supplemented with monensin. Rev. Bras. Saúde Prod. Anim., 13(4): 11801196

GOI, 2016. Press Information Bureau. Government of India. Ministry of Finance.

Hagawane, S. D., Shinde, S. B. and Rajguru, D. N. 2009. Haematological and blood biochemical profile in lactating buffaloes in and around Parbhani city. Vet. World, 2: 467-469.

Haimoud, D. A., Vernay, M., Bayourthe, C. and Moncoulon, R. 1995. Avoparcin and monensin effects on the digestion of nutrients in dairy cows fed a mixed diet. Can J. Anim. Sci., 74: 379-385.

Haimoud, D. A., Vernay, M., Bayourthe, C. and Moncoulon, R. 1995. Avoparcin and monensin effects on the digestion of nutrients in dairy cows fed a mixed diet. Can J. Anim. Sci., 74: 379-385.
Helal, F. I. S. and Lasheen, M. A. 2008. The Productive Perforance of Egyptian Dairy Buffaloes Receiving Biosynthetic Bovine Somatotropin (rbST) with or Without Monensin. American Eurasian J. Agric. \& Environ. Sci., 3(5): 771-777.

Helal, F. I. S. and Lasheen, M. A. 2008. The Productive Perforance of Egyptian Dairy Buffaloes Receiving Biosynthetic Bovine Somatotropin (rbST) with or Without Monensin. American Eurasian J. Agric. \& Environ. Sci., 3(5): 771-777.

Kalasariya, R. M., Dhami, A. J., Hadiya, K. K, Borkhatariya, D. N. and Patel, J. A. 2017. Effect of peripartum nutritional management on plasma profile of steroid hormones, metabolites, and postpartum fertility in buffaloes. Vet. World, 10(3): 302-310.

Lamba, J. S., Grewal, R. S., Ahuja, C. S., Malhotra, P. and Tyagi, N. 2013. Effect of Monensin on the Milk Production, Milk Composition, Rumen Metabolism and Blood Biochemical Profile in Crossbred Cows. Indian J. Anim. Nutr., 30(1): $38-42$.

Marini, J.C., Van Amburgh, M.E., 2005. Partition of nitrogen excretion in urine and the feces of Holstein replacement heifers. J. Dairy Sci. 88:1778-1784.

Mills, J.A.N., L. A. Crompton, A. Bannink, S. Tamminga, J. Moorby and C. K. Reynolds. 2009.

MOA, 2008. Basic Animal Husbandry Statistics, AHS Series 11, Department of Animal Husbandry and Dairying, Ministry of Agriculture, Government of India, New Delhi.

Mullins, C. R., Mamedova, L. K., Brouk, M.J., Moore, C. E., Green, H. B., Perfield, K. L., Smith, J. F., Harner, J. P. and Bradford, B. J., 2011. Effects of monensin on metabolic parameters, 
feeding behavior, and productivity of transition dairy cows J. Dairy Sci., 95: 1323-1336.

Ndlovu, T. M. Chimonyo, M., Okoh, A. I., Muchenje, V., Dzama, K., Dube, S. and Raats, J. G. 2007. Assessing the nutritional status of beef cattle; current practices and future prospects. Afr. $J$. biotechnol., 6: 2727-2734.

Oenema, O.,Wrage, N.,Velthof, G.L., Groenigen, J.W.V., Dolfing, J. and Kuikman, P.J. 2005. Trends in global nitrous oxide emissions from animal production systems. Nutrient Cycling in Agroecosystems. 72: 51-65.

Pambu-Gollah, R. P., Cronje, P. B. and Casey, N. H. 2000. An evaluation of the use of blood metabolite concentrations as indicators of nutritional status in free ranging goats. S. Afr. J. Anim. Sci., 30: 115-120.

Poos, M. I., Hanson, T. L. and Klopfenstein, T. J. 1979. Monensin effects on diet digestibility, ruminal protein bypass and microbial protein synthesis. $J$. Anim. Sci., 48: 1516-1524.

Predicting methane emissions and nitrogen excretion from cattle. J. Agric. Sci. 147:741.

Prusty, S. 2015. Metabolizable protein and energy requirements for buffalo calves fed on low methane producing rations. Ph.D. thesis, NDRI, Deemed University, Karnal (Haryana), India.

Rodehutscord, M. 2013. Effects of monensin and tannin extract supplementation on methane production and other criteria of rumen fermentation in vitro and in long-term studies with sheep.
Dissertation. Universität Hohenheim.

Sharma, N. 2017. Metabolic profiling and nutrient utilization in transition cows fed DCAD based diet supplemented with oil and polyherbal preparation. M.V.Sc thesis. NDRI, Deemed University, Karnal (Haryana), India.

Shipe, W. F., Senyk, G. F. and Fountain, K. B. 1980. Modified copper soap solvent extraction method for measuring free fatty acids in milk. J. Dairy Sci., 63: 193-198.

Strategies for optimizing nitrogen use by ruminants. Animal 4:1184-1196.

Tamminga, S., 1996. A review on environmental impacts of nutritional strategies of ruminants. J. Anim. Sci., 74:3122-3124.

Tedeschi, L. O., Fox, D. G. and Tylutki, T. P. 2003. Potential Environmental Benefits of Ionophores in Ruminant Diets. J. Environ. Qual., 32: 15911602.

Vendraminia, T. H. A., Takiyaa, C. S., Silvaa, T. H., Zanferaria, F., Rentasa, M. F., Bertonia, J. C. Consentinia, C. E. C. Gardinala, R., Acedob, T. S. and Rennóa, F. P. 2016. Effects of a blend of essential oils, chitosan or monensin onnutrient intake and digestibility of lactating dairy cows. Anim. Feed Sci. Techno., 214: 12-21.

Yogi, R. K. 2017. Nutritional Evaluation of Rice Dried Distillers Grains with Soluble in Ration of Lactating Murrah Buffaloes. Ph.D. thesis submitted to ICAR-National Dairy Research Institute (Deemed University), Karnal, India.

\section{How to cite this article:}

Shiva Gupta, Madhu Mohini, S.S. Thakur and Goutam Mondal. 2018. Effect of Dietary Monensin Supplementation on Nitrogen utilization and Plasma metabolites in Lactating Murrah Buffaloes. Int.J.Curr.Microbiol.App.Sci. 7(07): 3838-3845. doi: https://doi.org/10.20546/ijcmas.2018.707.446 